\title{
ASSESSMENT OF DEGRADATION STATUS OF SOILS IN SELECTED AREAS OF OGBOMOSO, OYO STATE, NIGERIA
}

\author{
Ewetola, Esther Abosede ${ }^{a}$, Owoade, Folasade Mary ${ }^{b}$ \\ and ${ }^{*}$ Olatunji, Olayinka Olakunle ${ }^{\mathrm{c}}$
}

Department of Crop Production and Soil Science, Ladoke Akintola University of Technology,

P.M.B. 4000, Ogbomoso, Oyo State, Nigeria.

E-mail address: eaewetola@lautech.edu.ng ${ }^{a}$, fmowoade@lautech.edu.ng $^{b}$, ooolatunji@lautech.edu.ng ${ }^{\mathrm{c}}$.

*Corresponding author: ola_marcus@yahoo.com / ooolatunji@lautech.edu.ng

Keywords: Soil degradation, cultivated soils, fallowed soils, sustainability.

\begin{abstract}
The assessment of degradation status of soils in selected areas of Ogbomoso, Oyo state was carried out. The soil physical and chemical properties were evaluated using mini pits and surface sampling. The laboratory results obtained were compared with the standard indicators and criteria for land degradation assessment according to FAO, 1979. The results revealed that most of the cultivated parts of the study sites were very highly degraded compared to the soil under vegetative fallow which were moderately degraded. The textural class of the soil ranged from loamy sand to sandy loam. Saturated hydraulic conductivity ranged from 1.54 to $3.4 \mathrm{~cm} \mathrm{hr}^{-1}$ corresponding low to moderate permeability. Bulk density ranged from 1.53 to $1.60 \mathrm{~g} \mathrm{~cm}^{-3}$. Organic matter was very low in all the study sites. Available phosphorus was low in all the locations. Total nitrogen was predominantly low in most of the cultivated and fallow soils. Exchangeable Sodium Percentage (ESP) of the sites depicted that most of the soils were slightly sodic. Summarily, the soil physical and chemical properties status when compared with the FAO standard show that the area either cultivated or fallow is under degradation. In order to optimize crop production in these areas, there may be need to introduce soil conservation strategies. The practice may include use of crop residues, green manure or poultry manure to boost soil fertility. Also regular monitoring of the fertility status of the soils is required.
\end{abstract}

\section{INTRODUCTION}

Land degradation is a decline in land quality caused by human activities and has been a major global issue and will continuing to remain high on the international agenda in the 21st century (Eswaran, et al., 2001). Soil degradation literally refers to the impairment of natural quality of soil component of any ecosystem. These soils have their natural potentials threatened, such that protection and rehabilitation is absolutely indispensable and inevitable. Soil degradation can be considered in terms of the loss of actual or potential productivity or utility as a result of natural or anthropic factors; it is the decline in land quality or reduction in its productivity. In the context of productivity, land degradation results from a mismatch between land quality and land use (Beinroth et al., 1994). The importance of land degradation among global environmental issues is enhanced because of its impact on world food security and quality of the environment. In the developing countries where a large proportion of human population depend almost entirely on land resources for their sustenance, there are increasing competing demands for land utilization such as grazing, fish pond, construction, quarrying, crop farming amongst others (Lal, 1994).

Important among physical processes are a decline in soil structure leading to crusting, compaction, erosion, desertification, anaerobism, environmental pollution, and unsustainable use of natural resources. Significant chemical processes include acidification, leaching, salinization, decrease in cation retention capacity, and fertility depletion. While biological processes include 
reduction in total and biomass carbon, and decline in land biodiversity, high soil and air temperature. Soil structure is the important property that affects all three degradative processes. Thus, land degradation is a biophysical process driven by socio economic and political causes.

Soil is currently undervalued in our food production system. Methods of agriculture that degrade the soil are profitable in the short term under our current system of accounting. This is because the losses of natural capital due to soil erosion or degradation are invisible in conventional economic accounts, and not included directly in the costs of food production.

Soil degradation that results in soil compaction and reductions in the soil's inherent fertility is compensated for by increases in purchased agricultural inputs, such as fertilizer. These inputs can mask, or compensate for the degradation of our soils by allowing crop yields to be sustained and profitable in the short term, at the expense of long-term productivity. In order to achieve genuine progress in agriculture, society as a whole must ensure that soil quality is maintained or improved according to a set of proposed indicators. They can be tracked over time to help us achieve optimal long-term ecological productivity. The soil quality and productivity indicators proposed here include soil organic matter (or soil organic carbon); soil structure; soil conservation; and soil foodweb health.

There are many problems that leads to Degradation of soil in Ogbomoso and the environ; the peak of these problems are Agronomic problem, possibly the genesis of these problems emanates from the blowing of high velocity wind, rain of high intensity, strong leaching in humid region and drought condition in dry regions. More so, the problem of over pumping of underground water for irrigation purposes, deforestation of fragile land, over cutting of vegetation, shifting cultivation, overgrazing and imbalanced fertilizer used as well as non-adoption of soil conservation management practices.

Five Local Government Areas of Ogbomoso were selected to be the scope of this study. The areas were chosen following a consistence farming pattern and exposure of soil to erosion as a result of continuous ploughing the land.

The main aim of this study is to assess the degree of degradation of soils in selected areas of Ogbomoso, Oyo State using some quality indicators to: (1) Establish the degree of degradation of the soil of the study area using standard indicator and criteria for soil degradation assessment (FAO, 1979). (2) Suggest modest recommendations on the rehabilitation strategies for the proper management of such degraded soils.

\section{MATERIALS AND METHODS}

Description of the Experimental Sites

The field work was carried out in five different Local Government areas of Ogbomoso where the past land use histories was obtained though interview and interaction with the local farmers. The climate of Ogbomoso area can be described as fairly hot, tropical marked wet and dry season. There is usually a short period of harmattan between these season i.e. the wet and dry season. The mean annual rainfall is about $1400 \mathrm{~mm}$ while the mean annual temperature is about $27^{\circ} \mathrm{C}$. The vegetation can be referred to as Southern Guinea Savannah. The five local governments chosen are as follows:

The location $\mathrm{N} 07^{\circ} 28.675^{\prime}$ and $\mathrm{N} 07^{\circ} 28.756^{\prime}$ with longitude E004 $07.219^{\prime}$ and E004 ${ }^{\circ} 07.229^{\prime}$. The elevation was $273.41 \mathrm{~m}$

- Ogbomoso North Local Government area, Lautech Teaching and Research Farm, which lies within latitude $\mathrm{N} 08^{\circ} 10.233^{\prime}$, longitude E004 ${ }^{\circ} .479^{\prime}$ Elevation of $1189 \mathrm{ft}$.

- Ogbomoso South Local Government area, Oke Ofuru village, with the description coordinates of $\mathrm{N} 08^{\circ} 06.113^{\prime}, \mathrm{E} 004^{\circ} 13.468^{\prime}$ and elevation of $1088 \mathrm{ft}$.

- Ogo Oluwa Local Government area, Orile Oje Ijeru village, with the description coordinate of $\mathrm{N} 08^{\circ} 04.236^{\prime}, \mathrm{E} 004^{\circ} 12.298^{\prime}$ and elevation of $981 \mathrm{ft}$. 
- Orire Local Government area, Aiyekale village with the description coordinate of $\mathrm{N} 08^{\circ} 15.289^{\prime}$, E $004^{\circ} 16.468^{\prime}$ and the elevation of $952 \mathrm{ft}$.

- Surulere local government - Kere Araro village with the description coordinate of $\mathrm{N} 08^{\circ} 15.289^{\prime}, \mathrm{E} 004^{\circ} 16.468^{\prime}$ and the elevation of $952 \mathrm{ft}$.

\section{SOIL SAMPLING}

Soil sample was collected in each of the study site on an area of 2 hectare of land using core sampler and soil auger at 100 by $100 \mathrm{~m}$ distance at the depth of $0-15 \mathrm{~cm}$ and $15-30 \mathrm{~cm}$. soil samples were collected from fallowed land and cultivated land and labeled A and B respectively.

Profile pits of $75 \mathrm{~cm}$ by $75 \mathrm{~cm}$ by $75 \mathrm{~cm}$ was dug at each study site and soil samples were collected at identified horizons in each pit, air dried for a week, later crushed with ceramic and pestle and sieved through $2 \mathrm{~mm}$ sieve. The sieved samples were packed and labeled for routine laboratory analysis at International Institute of Tropical Agriculture (IITA), Ibadan.

Particle size analysis (PSA) was done by hydrometer method (Gee and Or, 2002), Bulk density were determined using minimally disturbed core samples $(7 \mathrm{~cm} \times 7 \mathrm{~cm})$ for each depth as described by Blake and Heritage (1986). The saturated hydraulic conductivities (Ks) were obtained in the laboratory using a constant head permeameter, place on undisturbed core samples (Khute, 1986). Soil $\mathrm{pH}$ was determined in water using 1:1, Available $\mathrm{P}$ was determined in the sand using Bray P-1 method (Bray and Kurtz, 1945). The available P in the extractant was subsequently determined by the method described by Murphy Riley, (1962). Organic carbon was analyzed by dichromate wet oxidation method of Nelson and Sommers, (1982). Exchangeable Sodium Percentage (ESP) was calculated by dividing exchangeable sodium by CEC. Effective Cation Exchange Capacity (ECEC) was calculated by summing up the exchangeable bases plus the exchangeable acidity. Cation Exchangeable Capacity (CEC) CEC was determined by neutral, 1N Ammonium acetate method. Determination of Total Nitrogen was done by the Kjeldahl Method using a digestion mixture of $350 \mathrm{ml} \mathrm{H}_{2} \mathrm{O}_{2}, 0.42 \mathrm{~g}$ Se powder, $14 \mathrm{~g} \mathrm{Li}_{2} \mathrm{SO}_{4} \cdot \mathrm{H}_{2} \mathrm{O}$ and $420 \mathrm{~mL}$ conc. $\mathrm{H}_{2} \mathrm{SO}_{4}$ (Akinremi et al., 2003).

Table 1: Indicators and criteria for land degradation assessment

\begin{tabular}{lllll}
\hline Indicator & \multicolumn{4}{c}{ Degree of Degradation } \\
\hline & 1 & 2 & 3 & 4 \\
soil bulk density $(\mathrm{g} / \mathrm{cm})$ & $<1.5$ & $1.5-2.5$ & $2.5-5$ & $<5$ \\
permeability $(\mathrm{cm} / \mathrm{hr})$ & $<1.25$ & $1.25-5$ & $5-10$ & $>20$ \\
content of Nitrogen Element (multiple & $>0.13$ & $0.13-0.10$ & $0.10-0.08$ & $<0.08$ \\
decrease N(\%) & & & & \\
content of Phosphorus Element ( Cmol/Kg) & $>8$ & $8-7$ & $7-6$ & $<6$ \\
K content (cmol kg) & $>0.16$ & $0.16-0.14$ & $0.14-0.12$ & $<0.12$ \\
Content of ESP & $<10$ & $10-25$ & $25-50$ & $<50$ \\
Content of humus in soil & $>2.5$ & $2.5-2$ & $2-1.0$ & $<1.0$ \\
Content of base saturation & $<2.5$ & $2.5-5$ & $5-10$ & $>10$ \\
\hline
\end{tabular}

Source: FAO (1979)

Key: Class 1: Non slightly degraded

Class2: Moderately degraded

Class3: Highly degraded

Class 4: Very highly degraded 


\section{RESULTS AND DISCUSSIONS}

\section{Physical properties of the soils in the study area}

The results obtained from the study are presented in Table 1. Particle size from 20 different sampling points indicated different textural classes / composition of the soils. Although textural classes are one of the intensive properties of the soil that is not easily affected by management practices or land use, which are rather permanent and often used to characterized the soil physical make up (Jenny, 1980). The soils in the fallow plots had higher Clay content compare with the cultivated plots (Table 2), especially at two locations (KF and STF). This is in line with the observation of Troech and Thompson (1993) who deduced that good management strategies could slightly improve the clay content of the soil. However, this does not suggest that good management practices can alter the textural classes of a soil within a short time. According to Fitz-Patrick (1986), the textural classes of a given soil are directly related to the weathering history of the soil in conjunction with the parent materials as influenced by climate over time. The texture of the soil has high influence on the physical and chemical properties of the soil which are used as quality indicator for soil quality assessment.

Other physical properties that were used for assessment of the physical degradations of the soils of the studied site indicated that on permeability rating the soils were highly degraded (HD), although LF \& LP were moderately degraded (Table 4) using FAO (1979) critical levels.

Furthermore the soils were all moderately degraded (MD) with respect to bulk density (BD) in all the locations both on fallowed and cultivated farms. The correlation between BD, Clay and OM was significant. This implies that the lower BD in the fallowed part compared with the cultivated were indication of lower clay content and OM in the cultivated farms. This shows that BD of the soil was influence by the OM contents. The continuous cultivation of the soils tends to modify the soil BD and pore size distribution since the operation loosen soil granulates and crushes the soil particles, however this has negative implication on the OM which get quickly decomposed as a result of breaking into smaller pieces and burring into the soil. Although this observation opposes the report of Ojeniyi (1989) and Ike (1986) whose work reported high BD under untilled soil compare to cultivated ones. The observed values were a bit high than suggested by Kayombo and Lal (1994) who stated $1.35-1.5 \mathrm{gcm}^{-3}$ as critical BD for cassava production in an alfisol.

Table 2: Physical properties of the soils of the study area

\begin{tabular}{|c|c|c|c|c|c|c|c|c|}
\hline Location & $\begin{array}{l}\text { Depth } \\
(\mathrm{cm})\end{array}$ & $\begin{array}{l}\text { Bulk Density } \\
\left(\mathrm{gcm}^{-3}\right)\end{array}$ & $\begin{array}{l}\text { Total porosity } \\
\left(\mathrm{m}^{3} / \mathrm{m}^{3}\right)\end{array}$ & $\begin{array}{l}\text { Sat. Hydr. Conc. } \\
\left(\mathrm{cmhr}^{-1}\right)\end{array}$ & $\begin{array}{c}\text { Sand } \\
(\%)\end{array}$ & $\begin{array}{l}\text { Silt } \\
(\%)\end{array}$ & $\begin{array}{l}\text { Clay } \\
(\%)\end{array}$ & $\begin{array}{c}\text { Textural } \\
\text { class }\end{array}$ \\
\hline $\mathrm{KP}$ & $0-15 \mathrm{~A}$ & 1.56 & 0.41 & 2.14 & 80.0 & 8 & 12 & Sandy loam \\
\hline KP & $15-30 \mathrm{~A}$ & 1.55 & 0.42 & 1.91 & 81.0 & 6 & 13 & Sandy loam \\
\hline $\mathrm{KF}$ & $0-15 B$ & 1.53 & 0.42 & 1.54 & 75.0 & 11 & 14 & Sandy loam \\
\hline $\mathrm{KF}$ & $15-30 \mathrm{~B}$ & 1.53 & 0.42 & 1.54 & 77.0 & 9 & 14 & Sandy loam \\
\hline AP & $0-15 \mathrm{~A}$ & 1.57 & 0.41 & 2.43 & 79.0 & 10 & 11 & Sandy loam \\
\hline AP & $15-30 \mathrm{~A}$ & 1.57 & 0.41 & 2.43 & 79.0 & 10 & 11 & Sandy loam \\
\hline $\mathrm{AF}$ & $0-15 B$ & 1.57 & 0.41 & 2.43 & 79.0 & 10 & 11 & Sandy loam \\
\hline $\mathrm{AF}$ & $15-30 \mathrm{~B}$ & 1.57 & 0.41 & 2.43 & 79.0 & 10 & 11 & Sandy loam \\
\hline OP & $0-15 \mathrm{~A}$ & 1.59 & 0.40 & 2.96 & 81.0 & 9 & 10 & Loamy sand \\
\hline OP & $15-30 \mathrm{~A}$ & 1.57 & 0.41 & 2.43 & 79.0 & 10 & 11 & Loamy sand \\
\hline OF & $0-15 B$ & 1.58 & 0.41 & 2.46 & 81.0 & 8 & 11 & Loamy sand \\
\hline $\mathrm{OF}$ & $15-30 \mathrm{~B}$ & 1.57 & 0.40 & 2.43 & 79.0 & 10 & 11 & Loamy sand \\
\hline STP & $0-15 \mathrm{~A}$ & 1.61 & 0.39 & 3.51 & 83.5 & 7.5 & 9 & Loamy sand \\
\hline STP & $15-30 \mathrm{~A}$ & 1.61 & 0.39 & 3.51 & 83.5 & 7.5 & 9 & Loamy sand \\
\hline STF & $0-15 B$ & 1.55 & 0.42 & 1.90 & 76.0 & 11 & 13 & Loamy sand \\
\hline STF & $15-30 \mathrm{~B}$ & 1.53 & 0.42 & 1.54 & 74.0 & 12 & 14 & Loamy sand \\
\hline LAP & $0-15 \mathrm{~A}$ & 1.56 & 0.41 & 2.37 & 80.0 & 8 & 12 & Sandy loam \\
\hline LAP & $15-30 \mathrm{~A}$ & 1.57 & 0.41 & 2.70 & 80.0 & 9 & 11 & Sandy loam \\
\hline LAF & $0-15 B$ & 1.60 & 0.40 & 3.20 & 82.0 & 8.5 & 9.5 & Sandy loam \\
\hline LAF & $15-30 \mathrm{~B}$ & 1.56 & 0.41 & 2.12 & 80.0 & 8 & 12 & Sandy loam \\
\hline
\end{tabular}

Key: A - Ploughed, B - Fallowed, KP - Kereararo ploughed site (Surulere local government area), KF - Kereararo fallowed site (Surulere local government area), AP - Aiyekale ploughed site (Orire local government area), AF Aiyekale fallowed site (Orire local government area), OP - Orileoje ploughed site (Ogooluwa local government area), OF - Orileoje ploughed site (Ogooluwa local government area), STP - St Ferdinand ploughed site (Ogbomoso south local government), STF - St Ferdinand fallowed site (Ogbomoso south local government), LAP - LAUTECH ploughed site (Ogbomoso north local government), LAF - LAUTECH fallowed site (Ogbomoso north local government) 


\section{Chemical properties of the soils of the study areas.}

The result of the chemical analysis of the soils is presented in Table 3. Generally the $\mathrm{pH}$ of the soils was moderately to slightly acidic $(5.9-6.4)$. This is considered reasonable for plant growth and development in this agro-ecological zone. According to FAO (1979) indicators and criteria for land degradation assessment, available phosphorus was very highly degraded (VHD) in all the soils of the study sites (Table 4). Phosphorous is the second most the limiting element influencing plant growth and crop production throughout the world. Its inadequacy is very pronounced and can cause a major lose to the farmer if not supplied adequately. Agbede (2009) recommended $225 \mathrm{~kg} /$ ha or 4.5 bags of $\mathrm{P}$ for soils that are low in available $\mathrm{P}$ (less than $8.0 \mathrm{ppm}$ ) for maize production. In all the sites the $\mathrm{P}$ is less than the amount suggested by Agbede (2009) therefore there is need for a concerted effort to improve the $\mathrm{P}$ in these soils for sustainable agricultural production.

Table 3: Soil quality (QI) indicators for land degradation assessment

\begin{tabular}{|c|c|c|c|c|c|c|c|c|c|}
\hline $\begin{array}{c}\text { Loca- } \\
\text { tion }\end{array}$ & $\begin{array}{l}\text { Depth } \\
\text { (cm) }\end{array}$ & $\begin{array}{c}\text { B.D. } \\
\left(\mathrm{gcm}^{-3}\right)\end{array}$ & $\begin{array}{c}\text { Permeability } \\
(\mathrm{cm} / \mathrm{hr})\end{array}$ & $\begin{array}{c}\text { B.Sat } \\
(\%)\end{array}$ & $\begin{array}{c}N \\
(\%)\end{array}$ & $\begin{array}{c}\mathbf{P} \\
(\mathbf{p p m})\end{array}$ & $\begin{array}{c}\mathrm{K} \\
(\mathrm{cmol} / \mathrm{kg})\end{array}$ & $\begin{array}{l}\text { ESP } \\
(\%)\end{array}$ & $\begin{array}{l}\text { Om } \\
(\%)\end{array}$ \\
\hline $\mathbf{K P}$ & $0-15 \mathrm{~A}$ & 1.56 & 2.14 & 5.95 & 0.08 & 3.46 & 0.32 & 2.78 & 1.41 \\
\hline $\mathbf{K P}$ & $15-30 \mathrm{~A}$ & 1.55 & 1.91 & 4.66 & 0.06 & 2.65 & 0.30 & 3.44 & 1.12 \\
\hline KF & $0-15 B$ & 1.53 & 1.54 & 7.82 & 0.12 & 2.48 & 0.24 & 2.12 & 1.92 \\
\hline KF & $15-30 \mathrm{~B}$ & 1.53 & 1.54 & 5.60 & 0.07 & 5.61 & 0.24 & 2.86 & 1.13 \\
\hline $\mathbf{A P}$ & $0-15 \mathrm{~A}$ & 1.57 & 2.43 & 2.25 & 0.50 & 2.67 & 0.08 & 4.66 & 0.86 \\
\hline $\mathbf{A P}$ & $15-30 \mathrm{~A}$ & 1.57 & 2.43 & 2.08 & 0.49 & 2.45 & 0.09 & 5.17 & 0.84 \\
\hline $\mathbf{A F}$ & $0-15 B$ & 1.57 & 2.43 & 2.72 & 0.52 & 2.63 & 0.15 & 6.26 & 0.90 \\
\hline $\mathbf{A F}$ & $15-30 \mathrm{~B}$ & 1.57 & 2.42 & 2.13 & 0.41 & 1.55 & 0.06 & 6.89 & 0.71 \\
\hline OP & $0-15 \mathrm{~A}$ & 1.59 & 2.96 & 4.48 & 0.36 & 6.21 & 0.24 & 5.34 & 0.62 \\
\hline OP & $15-30 \mathrm{~A}$ & 1.57 & 2.43 & 4.56 & 0.32 & 4.25 & 0.24 & 5.05 & 0.54 \\
\hline OF & $0-15 B$ & 1.58 & 2.46 & 1.74 & 0.43 & 2.69 & 0.13 & 9.58 & 0.73 \\
\hline OF & $15-30 \mathrm{~B}$ & 1.57 & 2.43 & 1.54 & 0.30 & 1.34 & 0.13 & 10.82 & 0.52 \\
\hline STP & $0-15 \mathrm{~A}$ & 1.61 & 3.51 & 2.96 & 0.50 & 4.44 & 0.18 & 6.00 & 0.86 \\
\hline STP & $15-30 \mathrm{~A}$ & 1.61 & 3.51 & 2.84 & 0.50 & 3.10 & 0.18 & 6.75 & 0.86 \\
\hline STF & $0-15 B$ & 1.55 & 1.90 & 4.96 & 0.59 & 1.90 & 0.24 & 8.82 & 1.01 \\
\hline STF & $15-30 \mathrm{~B}$ & 1.53 & 1.54 & 2.41 & 0.48 & 1.77 & 0.19 & 8.20 & 0.83 \\
\hline LAP & $0-15 \mathrm{~A}$ & 1.56 & 2.37 & 3.27 & 0.53 & 3.04 & 0.25 & 5.32 & 0.91 \\
\hline LAP & $15-30 \mathrm{~A}$ & 1.57 & 2.70 & 3.19 & 0.50 & 2.37 & 0.24 & 5.42 & 0.86 \\
\hline LAF & $0-15 B$ & 1.60 & 3.20 & 3.36 & 0.29 & 4.13 & 0.24 & 4.70 & 0.50 \\
\hline LAF & $15-30 \mathrm{~B}$ & 1.56 & 2.12 & 2.88 & 0.43 & 2.54 & 0.21 & 5.56 & 0.74 \\
\hline
\end{tabular}

Key: A - Ploughed, B - Fallowed, KP - Kereararo ploughed site (Surulere local government area), KF - Kereararo fallowed site (Surulere local government area), AP - Aiyekale ploughed site (Orire local government area), AF Aiyekale fallowed site (Orire local government area), OP - Orileoje ploughed site (Ogooluwa local government area), OF - Orileoje ploughed site (Ogooluwa local government area), STP - St Ferdinand ploughed site (Ogbomoso south local government), STF - St Ferdinand fallowed site (Ogbomoso south local government), LAP - LAUTECH ploughed site (Ogbomoso north local government), LAF - LAUTECH fallowed site (Ogbomoso north local government)

Percentage Nitrogen content was non-slightly degraded in most sites except in kere araro village in Surulere local government area where $\% \mathrm{~N}$ ranged from 0.06 to $0.12 \%$ indicating a moderate to very highly degraded situations. percentage Nitrogen. Table 3 indicates a low to moderate availability of Nitrogen. This could be a reflection of the soil amendment strategies of the farmers or as a result of legume crops which load just been recently harvested in the previous 
planting season. Nitrogen is a key nutrient in soil quality indicator for plant growth. Agbede (2009) referred to $\mathrm{N}$ as the most important essential element needed for plant growth, development and reproduction. It is by far the most limiting element especially in the tropics where organic matter decomposition is rapid and Nitrogen released from the process is easily lost through leaching or evaporation. The exposure of the soil to sheet erosion washes away the top soil and the nutrient in them. For soil that are low in Nitrogen ( less than $0.15 \mathrm{cmol} / \mathrm{kg}$ ), Agbede (2009) recommended an application of $200 \mathrm{~kg}$ of Urea per hectare.

With respect to exchangeable sodium percentage (ESP) the soils were non slightly degraded (SD) in all the locations and at all depths. The degree of degradation with respect of potassium $\left(\mathrm{k}^{+}\right)$ was non-slightly degraded (SD) in about $70 \%$ of the studied sites. Only Aiyekale site was very highly degraded (VHD) both at fallowed and cultivated sites. However at $0-15 \mathrm{~cm}$ of Aiyekale fallowed land was moderately degraded (MD). Also at Orileoje fallowed site K was HD which signifies a need for soil amendment especially $\mathrm{K}$ as it deficiency may inhibits the uptake of some other nutrients in both Aiyekale and Orilaoje locations.

Table 4: Assessment of Individual Soil Quality Indicators (QI)

\begin{tabular}{|c|c|c|c|c|c|c|c|c|c|}
\hline Location & $\begin{array}{l}\text { Depth } \\
\text { (cm) }\end{array}$ & $\begin{array}{c}\text { B.D. } \\
\left(\mathrm{gcm}^{-3}\right)\end{array}$ & $\begin{array}{c}\text { Permeability } \\
(\mathrm{cm} / \mathrm{hr})\end{array}$ & $\begin{array}{c}\text { B.Sat } \\
\left(\mathrm{m}^{3} / \mathrm{m}^{3}\right)\end{array}$ & $\begin{array}{c}\mathrm{N} \\
(\%)\end{array}$ & $\begin{array}{c}P \\
(\%)\end{array}$ & $\begin{array}{c}\mathrm{K} \\
(\mathrm{cmol} / \mathrm{kg})\end{array}$ & $\begin{array}{l}\text { ESP } \\
(\%)\end{array}$ & $\begin{array}{l}\text { Om } \\
(\%)\end{array}$ \\
\hline $\mathbf{K P}$ & $0-15 \mathrm{~A}$ & $\mathrm{MD}$ & HD & HD & HD & VHD & SD & SD & HD \\
\hline $\mathbf{K P}$ & $15-30 \mathrm{~A}$ & MD & HD & $\mathrm{HD}$ & $\mathrm{HD}$ & VHD & SD & $\mathrm{SD}$ & HD \\
\hline KF & $0-15 B$ & MD & HD & MD & MD & VHD & SD & $\mathrm{SD}$ & HD \\
\hline KF & $15-30 \mathrm{~B}$ & MD & HD & HD & $\mathrm{HD}$ & VHD & SD & $\mathrm{SD}$ & HD \\
\hline $\mathbf{A P}$ & $0-15 \mathrm{~A}$ & MD & HD & SD & $\mathrm{SD}$ & VHD & VHD & $\mathrm{SD}$ & VHD \\
\hline $\mathbf{A P}$ & $15-30 \mathrm{~A}$ & MD & HD & SD & $\mathrm{SD}$ & VHD & VHD & $\mathrm{SD}$ & VHD \\
\hline $\mathbf{A F}$ & $0-15 B$ & MD & $\mathrm{HD}$ & MD & $\mathrm{SD}$ & VHD & MD & $\mathrm{SD}$ & VHD \\
\hline $\mathbf{A F}$ & $15-30 \mathrm{~B}$ & MD & HD & SD & $\mathrm{SD}$ & VHD & VHD & $\mathrm{SD}$ & VHD \\
\hline OP & $0-15 \mathrm{~A}$ & MD & HD & MD & $\mathrm{SD}$ & $\mathrm{HD}$ & $\mathrm{SD}$ & $\mathrm{SD}$ & VHD \\
\hline OP & $15-30 \mathrm{~A}$ & MD & $\mathrm{HD}$ & MD & $\mathrm{SD}$ & VHD & SD & $\mathrm{SD}$ & VHD \\
\hline OF & $0-15 B$ & MD & HD & SD & $\mathrm{SD}$ & VHD & HD & $\mathrm{SD}$ & VHD \\
\hline $\mathbf{O F}$ & $15-30 \mathrm{~B}$ & MD & HD & SD & $\mathrm{SD}$ & VHD & HD & $\mathrm{SD}$ & VHD \\
\hline STP & $0-15 \mathrm{~A}$ & MD & HD & MD & $\mathrm{SD}$ & VHD & SD & $\mathrm{SD}$ & VHD \\
\hline STP & $15-30 A$ & MD & HD & MD & $\mathrm{SD}$ & VHD & SD & $\mathrm{SD}$ & VHD \\
\hline STF & $0-15 B$ & MD & HD & MD & SD & VHD & SD & $\mathrm{SD}$ & VHD \\
\hline STF & $15-30 \mathrm{~B}$ & MD & HD & SD & $\mathrm{SD}$ & VHD & SD & $\mathrm{SD}$ & VHD \\
\hline LAP & $0-15 \mathrm{~A}$ & MD & MD & MD & $\mathrm{SD}$ & VHD & SD & $\mathrm{SD}$ & VHD \\
\hline LAP & $15-30 A$ & MD & MD & MD & $\mathrm{SD}$ & VHD & $\mathrm{SD}$ & $\mathrm{SD}$ & VHD \\
\hline LAF & $0-15 B$ & MD & MD & MD & $\mathrm{SD}$ & VHD & SD & $\mathrm{SD}$ & VHD \\
\hline LAF & $15-30 \mathrm{~B}$ & MD & MD & MD & $\mathrm{SD}$ & VHD & SD & $\mathrm{SD}$ & VHD \\
\hline
\end{tabular}

Key: A - Ploughed, B - Fallowed, HD - Highly degraded, SD - Non-slightly degraded, MD - Moderately degraded, VHD - Very highly degraded, KP - Kereararo ploughed site (Surulere local government area), KF - Kereararo fallowed site (Surulere local government area), AP - Aiyekale ploughed site (Orire local government area), AF Aiyekale fallowed site (Orire local government area), OP - Orileoje ploughed site (Ogooluwa local government area), OF - Orileoje ploughed site (Ogooluwa local government area), STP - St Ferdinand ploughed site (Ogbomoso south local government), STF - St Ferdinand fallowed site (Ogbomoso south local government), LAP - LAUTECH ploughed site (Ogbomoso north local government), LAF - LAUTECH fallowed site (Ogbomoso north local government)

The rating of base saturation (BS) indicated that the soil were moderately degraded (MD) in most of the sites, lautech ploughed and cultivated sites, St-Ferdmand and Orileoje locations while in kere-araro extent of degradation ranges from MD to HD. At Aiyekale ploughed and Orileoje fallowed it was SD (non-slightly degraded) with respect to BS. 
The biological degradation was more pronounced when compared with the physical and chemical degradation in all the sites studied. Kere araro soil both on fallowed land and cultivated land was highly degraded (HD) at both $0-15 \mathrm{~cm}$ and $15-30 \mathrm{~cm}$ depth. However, all other site were very highly degraded (VHD) in both depths with respect to Organic matter content (Table 4). This is an indication of very high biological degradation which is typical of a savanna soil. The values of organic matter $(\mathrm{OM})$ content in all the locations as presented in the table 3 were very low. This very low OM are indicative of very high biological degradation of all the soils of the study areas. The OM depletion may be in part due to crop uptake exacerbated by continuous cropping without adequate measures for nutrient replacement either through the use of inorganic fertilizer or other forms of soil conservation measures. One would have expected that the fallowed land would show an appreciable amount of OM, this may be due to rapid decomposition of plant residue as a result of high temperature that rapidly breaks down OM and inhibits Nitrogen fixation by rhizo-bacteria. Other land use practices such as bush burning which is very rampant in the savanna ecosystem could also be responsible for the destruction of OM content and even the microbial populace in the soils. As a result the soil flora and foam biodiversity is destroyed or reduced given ways to less OM content (Lai and Kang, 1982).

The importance of OM content is much more in explicable in view of the fact that $\mathrm{OM}$ serves as the bounding site for the availability of other nutrient, improvement of water transmission and root penetration (Agbim and Adeoye, 1991). Balasubramania (1990) reported that high rate of OM addition was needed to solve the problems of soil acidity arising from continuous cropping I west Africa Alfisols. The addition of animal wastes to increase the level of soil OM had been reported by Olatunji et al., (2012); Ojeniyi, (2000) and by Okpara and Mbagwu, (2003). Thus, proper management of organic matter content is highly desirable. Olatunji et al., (2012) reported an improvement in aggregate stability of the soil with the application of poultry manure. It is important to also incorporate leguminous crops into the cropping systems of the studied areas to improve the level of Nitrogen that would be fixed by Nitrogen-fixing bacteria.

\section{CONCLUSION}

An investigation into land degradation was conducted in 2013 planting season to assess the degree of degradation of the soils in some selected areas of Ogbomoso, Oyo State. The soil was classified according to USDA, (1998) criteria for description and it was find out that the soils were predominantly Alfisols. The study revealed that most of the soils (about $90 \%$ ) were highly degraded, even though, those of the fallowed plots that would have been expected to be better are showing signs of serious degradation.

\section{RECOMMENDATION}

Base on the findings of this study the following recommendations were proposed.

1. Application of mineral fertilizer to improve the Nitrogen, phosphorous and potassium content of the soils. It would be appropriate to suggest an application rate of $200 \mathrm{~kg} / \mathrm{ha}$ of urea for Nitrogen, $225 \mathrm{~kg} /$ ha of Phosphorous in the guinea savanna agro-ecological zones.

2. The use of organic manure such as cow dung and poultry droppings is encouraged to improve the productivity of these degraded soils. Also the left over crop residues should be ploughed back into the soil instead of burning them with fire.

3. A well-developed fertility enhancement programme should be put in place for proper monitoring of the fertility status of the soils. 


\section{References}

[1] Agbede O.O. Understanding soil and plant nutrition. $1^{\text {st }}$ Ed. (2009). pp.132 - 160

[2] Agbim, U.C. and Adeoye K.B. The role of crops residue in soil fertility maintenance and conservation. Organic fertilizer in the Nigeria agriculture: present and future . proceedings of a National Organic Fertilizer seminar, Held at Durba Hotel Kaduna, march 26 - 27, (1991).

[3] Akinremi, O.O., N. Armisen, A. Kashemand and H. H. JanzenEvaluation of analytical methods for total N and P in organic amendments. Communications in Soil Science and Plant Analysis, .(2003). 34, 2987-2997.

[4] Beinroth, F.H., Eswaran, H., Reich, P.F. and Van Den Berg, E. Land related stresses in agroecosystems. In: Stressed Ecosystems and Sustainable Agriculture, eds. S.M. Virmani, J.C. Katyal, H. Eswaran, and I.P. Abrol. New Delhi: Oxford and IBH. (1994).

[5] Blake, G.R., Hartge, K.H., 1986. Bulk density. In: Klute, A. (Ed.), Methods of Soil Analysis. Part 1, Physical and Minerological Methods, Agron. Monogr. 9. 2nd ed. ASA and SSSA, Madison, WI, pp. 364-367.

[6] Balasubramania. Long Term Fertilizer Trial on Alfisol in west Africa. In: Transaction of XIV International soil science society congress. Koyoto, Japan (Vol.4) Kyoto japan ISSS (1990)

[7] Bray, R. H. and Kurtz, L. T. Determination of total, organic and available forms of phosphate soils. Soil Science, 59, 39. (1945).

[8] Eswaran, H., Lal, R. \& Reich, P.F. Land degradation: an overview. In: Bridges, E.M.,I.D. Hannam, L.R. Oldeman, F.W.T. Pening de Vries, S.J. Scherr \& S. Sompatpanit (eds). Responses to land degradation. Proceedings of the Second International Conference on Land Degradation and Desertification, Khon Kaen, Thailand and New Delhi, Khon Kaen and Oxford Press, New Delhi, India. (2001).

[9] FAO/RAPA. The collection and analysis of land degradation data. RAPA Publication 1994/3. Bangkok: FAO/RAPA

[10] FAO. A framework for land evaluation. Soil resource development and conservation service: land and water development division, Rome, Italy. (1979).

[11] Fitz- Patrick F.A. An Introduction to Soil Science $2^{\text {nd }}$ Edition. Longman Scientific and Technical and John Willy and Sons Int. New York 266pp. (1986).

[12] Gee, G.W. and Or, D. Particle Size Analysis. Pp.255 -293. In J.H. Dane and G.C. Topp (eds) Methods of Soil Analysis, Part 4, Physical Methods. Soils Science Society of America. Book series No.5, Madison, Winconsin, USA. (2002).

[13] Ike, I.F. Soil and crop responses to different tillage practice in ferruginous soils in the Nigeria Savanna. Soil and Tillage Res. (1986). 6: $261-272$.

[14] ISRIC. Guidelines for the general assessment of the status of human-induced soil a degradation. Working paper \& Preprint 88/4. Wageningen [NL]: ISRIC (1988).

[15] Jenny, H. The Soil Resource, Origin and Behaviour. New York: Springer-Verlag. (1980). $110 \mathrm{pp}$

[16] Kayombo, B. and Lal, R. Response of tropical crops to soil compaction. In: Soil Compaction in Crop Production, eds. B.D. Sloane and C. Van Ouwerkkerk, 287-315. (1994). Amsterdam: Elsevier.

[17] Klute, A. Laboratory measurement of hydraulic conductivity of saturated soil. In: Black, C.A. (Ed.), Method of Soil Analysis. Part I, Agronomy 9. Am. Soc. Agron. Inc, Madison, WI, USA, (1965), pp. 210-211. 
[18] Lal, R. and Kang B.T. Management of organic matter in soils of the tropics in: Soil Management Abstract 302 - 4001 (2) 152 - 178. (1982).

[19] Lal, R. Tillage effects on soil degradation, soil resilience, soil quality, and sustainability. Soil Tillage Research, 27, 1-8. (1994).

[20] Nelson, D.w.and Sommers, L.E. Total carbon, organic carbon and organic matter. In : page, A.L. Miller, R.H. and Kenney, D.R. (eds.). methods of soil analysis, part 2. American society of Agronomy, Madison, Wisconsin Pp 539-579. (1982).

[21] Ojeniyi S.O. Investigation of ploughing requirement on the establishment of cowpea. Soil and Tillage Res. 14: 177 - 184, (1989).

[22] Ojeniyi S.O. Effect of goat manure on soil nutrient content and okra yield in rainforest area of Nigeria. Applied tropical Agriculture 5: 20 - 23, (2000).

[23] Okpara, M.I. and Mbagwu J.S.C. Effectiveness of cattle dung and swine waste as biofertilizers on an Ultisol at Nsukka. Land degradation, Agricultural productivity and rural poverty environmental implications. Procedings of the $28^{\text {th }}$ annual conference of soil science society of Nigeria, Umudike. Abia state Nigeria pp. 71 - 80. (2003).

[24] Olatunji, O.O., Aderinola, O. A., Babajide, P.A., Ewetola, E.A., Lawal, B.A., Owoade, F.M.,Oyeyiola, Y.B.and Olayiwola, A.O. Effect of poultry manure on soil physico-chemical properties, aggregate stability and biomass yield of Panicum maximum. International Journal of Current Research. Vol. 4, Issue, 04, pp.013-016. (2012).

[25] USDA, Natural Resource Conservation service. Soil quality indicators: Infiltration [online], USA. To be found at http://soils.usda.gov/sqi/publications/files/Infiltration.pdf> (1998). 